\title{
Pengembangan E-modul berdasarkan aplikasi Pdf Flipbook untuk meningkatkan kemampuan menulis dan kemampuan belajar mandiri peserta didik (E-module based on the corporate Pdf Flipbook application which is useful in the Covid-19 era)
}

\author{
Sania Nanda Safitri, Madziatul Churiyah*, Mohammad Arief, Fadia Zen \\ Universitas Negeri Malang, Jl. Semarang No. 5 Malang, Jawa Timur, Indonesia \\ *Penulis korespondensi, Surel: madziatul.churiyah.fe@um.ac.id
}

Paper received: 7-6-2021; revised: 21-6-2021; accepted: 28-6-2021

\begin{abstract}
Abstrak
Perkembangan pendidikan era globalisasi ditandai dengan berbagai macam produk teknologi informasi seperti modul cetak menjadi E-Modul. Dimasa pandemi virus Covid-19 pembelajaran yang semula dilakukan secara tatap muka langsung, pemerintah mengeluarkan kebijakan pembelajaran diubah secara daring dalam rangka menghindari penyebaran Covid-19. Bahan ajar yang semula modul cetak mengalami perkembangan menjadi E-Modul, dimana pembelajaran dilakukan secara Online yang lebih dikenal dengan Pembelajaran Jarak Jauh (PJJ) yakni peserta didik mengikuti proses pembelajaran melalui pembelajaran daring di rumah masing-masing. Sehingga penelitian ini bertujuan untuk menghasilkan E-Modul berbasis Aplikasi Flipbook PDF Corporate yang dapat dioperasikan menggunakan Laptop/PC atau Smartphone di perangkat pendidik dan peserta didik. Penelitian dan pengembangan ini menggunakan (Research and Development / R\&D) dari Borg and Gall yang telah dimodifikasi dan disesuaikan dengan kebutuhan penelitian. Instrumen pengumpulan data terdiri dari 2 jenis, yaitu data kuantitatif dan data kualitatif. Data kuantitatif berupa angket dan data kualitatif berupa wawancara, kritik dan saran. Teknik analisis data hasil belajar psikomotorik menggunakan SPSS versi 24, yaitu uji Independent Sample T-tes untuk mengetahui perbedaan hasil belajar aspek psikomotorik pada keterampilan menulis surat peserta didik. Hasil penelitian dan pengembangan ini adalah E-Modul berbasis Aplikasi Flipbook PDF Corporate yang dapat dioperasikan menggunakan Laptop/PC atau Smartphone di perangkat pendidik dan peserta didik pada mata pelajaran Korespondensi yang telah dinyatakan valid dan layak digunakan dalam pembelajaran Korespondensi oleh ahli materi, ahli E-Modul, dan 6 siswa uji coba kelompok kecil serta terbukti dapat meningkatkan keterampilan menulis surat dan kemandirian belajar secara signifikan pada uji coba kelompok besar. Sehingga dapat disimpulkan E-Modul berbasis Aplikasi Flipbook PDF Corporate layak dan efektif digunakan sebagai media pembelajaran untuk meningkatkan keterampilan menulis surat dan kemandirian pada mata pelajaran Korespondensi.
\end{abstract}

Kata kunci: e-modul emflicate; flipbook pdf corporate; keterampilan menulis surat; kemandirian belajar.

\section{Pendahuluan}

Perkembangan pendidikan di era globalisasi yang modern, saat ini sedang mengalami perubahan sistem bahan ajar siswa. Perubahan sistem bahan ajar telah mengalami perubahan yang cukup pesat, seperti perubahan perkembangan bahan ajar pendidikan dengan menggunakan pembelajaran sistem teknologi. Perkembangan pendidikan era globalisasi ini ditandai dengan banyaknya berbagai macam produk teknologi informasi yang modern seperti modul bahan cetak menjadi E-Modul. Pembelajaran ini merupakan inovasi pendidikan dalam ketersediaan sumber belajar yang variatif (Dewi, (2020). Dalam proses kegiatan pembelajaran peserta didik tidak hanya berinteraksi dengan tenaga pengajar sebagai salah satu sumber 
belajar, tetapi mencangkup interaksi dengan semua sumber belajar yang memungkinkan untuk dipergunakan dalam mencapai hasil (Abdullah, (2012). Dimasa pandemi virus Covid-19 bahan ajar untuk peserta didik telah mengalami perkembangan dari modul menjadi E-Modul, yang mana pembelajaran dilakukan secara Online yang lebih dikenal dengan Pembelajaran Jarak Jauh (PJJ) dimana peserta didik mengikuti proses pembelajaran melalui pembelajaran daring di rumah masing-masing. Pembelajaran daring saat ini memerlukan sumber bahan ajar yang tepat dengan memanfaatkan kemajuan teknologi informasi. Kemampuan pendidik dalam penguasaan teknologi informasi berbasis elektronik merupakan sebuah tuntutan yang tidak dapat dihindari. Kemajuan teknologi dalam kehidupan kita merupakan sesuatu yang tidak bisa dihindari, karena kemajuan teknologi akan semakin berjalan maju sesuai dengan kemajuan ilmu pengetahuan dan inovasi-inovasi yang diciptakan (Ngafifi, (2014). Kemajuan teknologi dalam perkembangan pendidikan salah satunya yaitu sumber bahan ajar seperti modul menjadi E-Modul. E-Modul merupakan bagian dari Electronic Based E-Learning yang memanfaatkan pembelajaran teknologi informasi dan komunikasi, terutama pada perangkat elektronik (Fausih and T, (2015).

Bahan ajar modul pada umumnya disajikan dengan bahan cetak kertas yang berisikan full teks dan gambar, namun modul elektronik ini dapat menampilkan yang berisikan full teks, gambar, video dan audio serta lebih simple. Pada dasarnya E-Modul memerlukan perangkat aplikasi untuk menyempurnakan hasil bahan ajar elektronik yang disebut Flipbook PDF Corporate. E-Modul yang dikembangkan dalam penelitian ini yaitu E-Modul berbasis aplikasi Flipbook PDF Corporate. Flipbook PDF Corporate merupakan sebuah perangkat lunak yang dirancang untuk mengkonversi file $P D F$ ke halaman yang dapat digerakkan bolak-balik publikasi digital seperti buku dan dapat menambahkan berbagai fitur seperti gambar, audio dan video (Sugianto et al., 2013).

Beberapa penelitian sebelumnya yang juga membahas tentang tema ini adalah (Sugianto et al., 2013; Fausih and T, 2015; Wirasari and Churiyah, 2016; Putra, Wirawan and Pradnyana, 2017; Fitriningtias and Churiyah, 2018; Shobahah, 2018; Wibowo and Pratiwi, 2018; Oktaviara and Pahlevi, 2019; Andini and Churiyah, 2020; Churiyah, Aulia and Eko, 2020)berdasarkan penelitian-penelitian tersebut dapat disimpulkan bahwa E-Modul berbasis Aplikasi Flipbook PDF Corporate yang dapat diakses secara Online maupun Offline dapat menyelesaikan masalah kesulitan dalam kegiatan pembelajaran serta meningkatkan keterampilan menulis surat dan kemandirian belajar peserta didik mata pelajaran Korespondensi.

Berdasarkan hasil wawancara dengan guru SMK Muhammadiyah 7 Gondanglegi mata pelajaran Korespondensi,didapati bahwa dalam proses pembelajaran Online yang diberikan kepada peserta didik masih terbatas dengan menggunakan bahan ajar seperti Handout, media pembelajaran seperti PowerPoint Fulltext dan yang memiliki buku cetak hanya guru dan sebagian peserta didik saja, sehingga para peserta didik kurang memahami materi pembelajaran yang disampaikan, menimbulkan kurang terampil dalam membuat surat dan merasakan kebosanan pada saat proses belajar Online atau Pembelajaran Jarak Jauh (PJJ). Power Point fulltext meskipun mempunyai fitur animasi dan gambar, tidak menutup kemungkinan peserta didik dalam memahami materi yang akan diajarkan tidak merasakan kebosanan, karena Power Point fulltext tidak menampilkan beberapa fitur yang ada di Power Point, seperti gambar, audio dan video. Mengingat pentingnya suatu bahan ajar untuk peserta didik dalam memenuhi kebutuhan proses belajar mengajar Online atau Pembelajaran Jarak Jauh (PJJ) dan peserta didik tidak memegang buku cetak, maka peneliti akan mengembangkan 
bahan ajar E-Modul berbasis Flipbook PDF Corporate pada mata pelajaran Korespondensi jurusan Otomatisasi dan Tata Kelola Perkantoran kelas X di SMK Muhammadiyah 7 Gondanglegi.

Penelitian-penelitian penembangan E-Modul umumnya menggunakan berbasis Aplikasi Flipbook (Widodo and Jasmadi, 2008; Shobahah, 2018; Oktaviara and Pahlevi, 2019). Akan tetapi, peneliti sebelumnya tidak menggunakan berbasis Aplikasi Flipbook PDF Corporate dan selain itu E-Modul dapat diakses melalui Smartphone secara online dan Laptop/PC secara Offline. Berdasarkan pada hal tersebut, peneliti memiliki inovasi dalam pengembangan bahan ajar yaitu E-Modul berbasis Aplikasi Flipbook PDF Corporate, dimana E-Modul pada penelitian ini berfokus pada mata pelajaran Korespondensi untuk meningkatkan keterampilan menulis surat dan kemandirian belajar peserta didik.

\section{Metode}

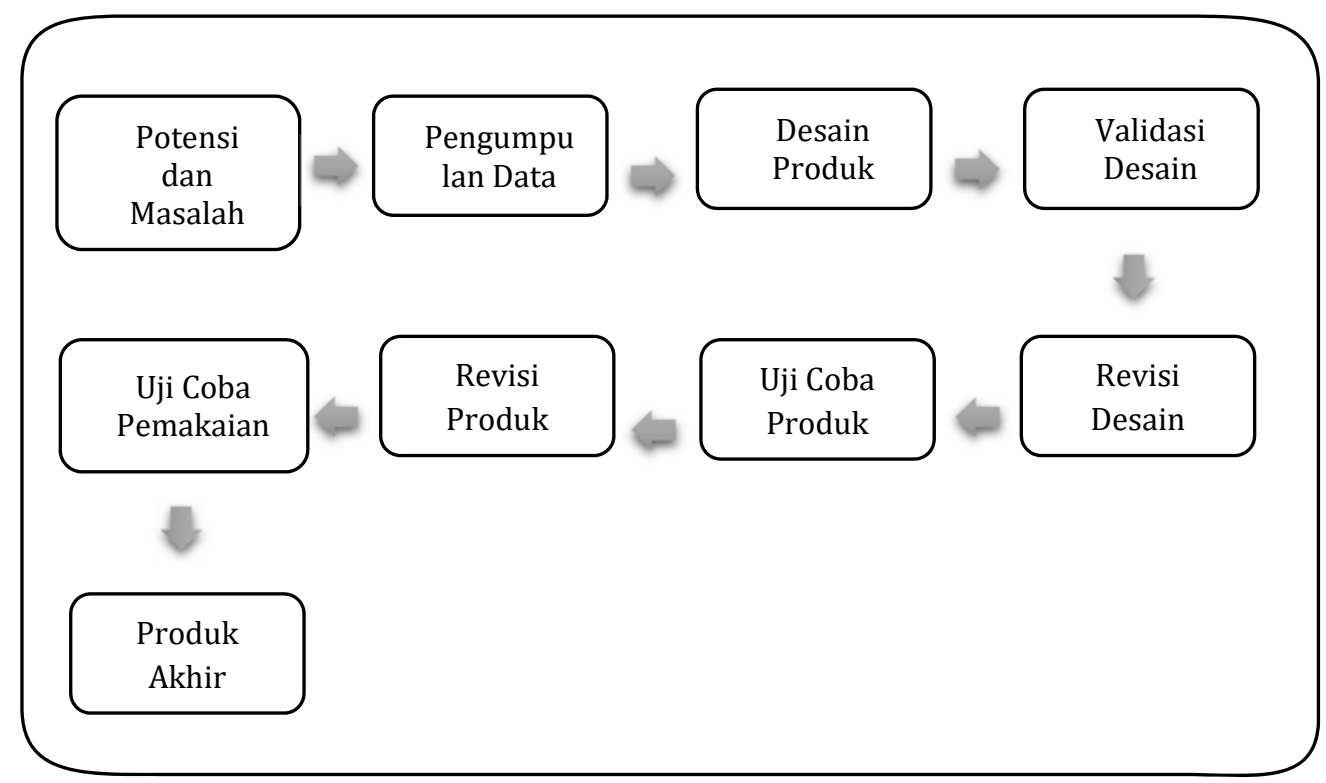

Gambar 1. Langkah-langkah Penelitian

Penelitian kali ini menggunakan metode penelitian dan pengembangan (Research and Development / R\&D) dari Borg and Gall yang telah dimodifikasi dan disesuaikan dengan kebutuhan penelitian. Metode penelitian R\&D (Research and Development) adalah metode penelitian yang digunakan untuk menghasilkan produk tertentu, dan menguji keefektifan produk tersebut (Sugiyono, 2006). Berdasarkan hal diatas metode penelitian R\&D (Research and Development) cocok untuk pengembangan E-Modul berbasis Aplikasi Flipbook PDF Corporate, karena prosedur lebih jelas, tepat, lengkap dan menarik untuk pembelajaran pendidik. Peneliti melakukan sembilan langkah mulai dari menganalisis potensi dan masalah yang ada pada lapangan hingga menghasilkan produk yang dikembangkan.

Langkah-langkah pertama yang dilakukan peneliti yaitu menganalisis potensi dan masalah terkait kegiatan pembelajaran daring di sekolah. Langkah kedua pengumpulan data yang dilakukan dengan wawancara serta observasi dalam kegiatan pembelajaran daring. Langkah ketiga desain produk yang diawali dengan merancang desain produk seperti 
penyusunan materi, pembuatan modul serta mengubah modul menjadi E-Modul. Langkah keempat validasi desain yang dilakukan oleh ahli materi, ahli E-Modul dan uji coba produk. Langkah kelima revisi desain pada produk yang kembangkan dengan acuan dalam validasi, saran, kritik dan masukan. Langkah keenam uji coba produk yang diuji cobakan kepada kelompok kecil yang melibatkan 6 peserta didik secara acak pada kelas X OTKP 2. Langkah ketujuh revisi produk dengan acuan pada hasil yang diperoleh dari angket ahli materi, angket ahli E-Modul dan angket pada uji coba produk kelompok kecil. Langkah kedelapan uji pemakaian yang melibatkan 34 peserta didik kelas X OTKP 1 SMK Muhammadiyah 7 Gondanglegi pada kelas eksperimen dan 27 peserta didik X OTKP 3 SMK Muhammadiyah 7 Gondanglegi kelas kontrol untuk melihat perbandingan keterampilan menulis surat dan kemandirian peserta didik yang berhubungan dengan pengembangan produk E-Modul. langkah kesembilan produk akhir yang artinya produk final dapat dikatakan valid atau layak digunakan jika tidak ada revisi, akan tetapi apabila dalam uji coba pemakaian pada kelompok besar terdapat kelemahan maka peneliti melakukan revisi sebelum valid atau layak digunakan.

Data yang dihasilkan pada penelitian ini meliputi data kualitatif dan data kuantitatif, hasil data dari validator E-Modul, validator materi dan peserta didik subjek uji coba produk (kelompok kecil) berupa tanggapan, pendapat, kritik dan saran secara umum tentang pengembangan media pembelajaran merupakan data kualitatif. Sedangkan dari para ahli validator uji coba produk (kelompok perseorangan), yang berupa dalam bentuk angka/skor penilaian angket merupakan data kuantitatif. Sedangkan hasil data dari uji coba pemakaian kelompok besar kelas eksperimen dan kelas kontrol pada keterampilan menulis surat menggunakan bantuan Aplikasi SPSS versi 24 dengan uji independent sample t-test dan kemandirian belajar menggunakan teknis analisis persentase.

\section{Hasil dan Pembahasan}

Produk yang dihasilkan dalam penelitian dan pengembangan ini adalah E-Modul berbasis Aplikasi Flipbook PDF Corporate untuk meningkatkan keterampilan menulis surat dan kemandirian belajar peserta didik pada mata pelajaran Korespondensi. E-Modul berbasis Aplikasi Flipbook PDF Corporate memiliki tampilan yang menarik melalui Gambar 2 berikut ini:

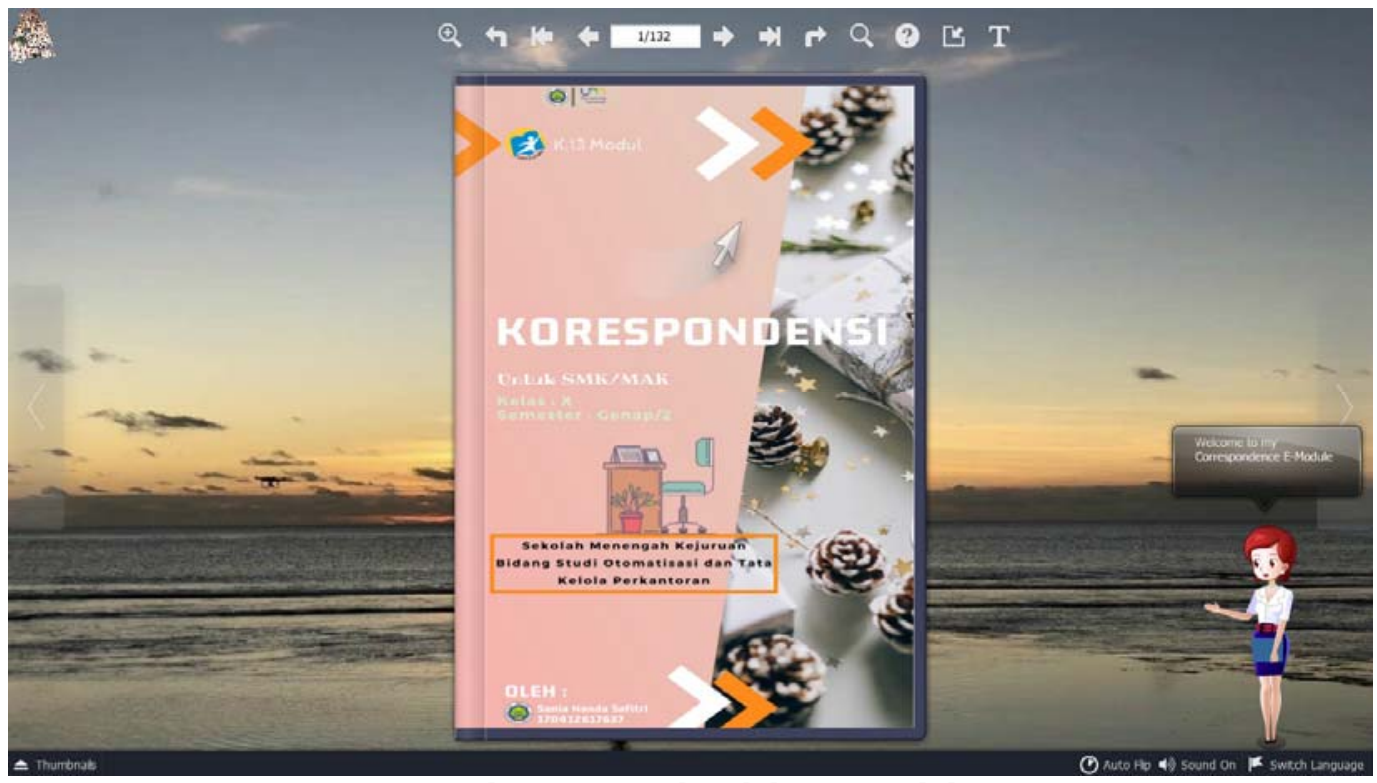

Gambar 2. Tampilan dalam E-Modul 
Hasil validasi E-Modul berbasis Aplikasi Flipbook PDF Corporate oleh ahli materi, ahli EModul, dan peserta didik uji coba kelompok kecil secara keseluruhan disajikan dalam Tabel 1 berikut ini:

Tabel 1. Data hasil validasi keseluruhan

\begin{tabular}{|c|c|c|c|c|c|}
\hline \multirow{2}{*}{ No } & \multirow{2}{*}{ Validasi } & \multicolumn{2}{|c|}{ Skor } & \multirow{2}{*}{$\begin{array}{l}\text { Persentase (\%) } \\
x=\frac{\sum x}{\sum x i} x 100 \%\end{array}$} & \multirow{2}{*}{$\begin{array}{l}\text { Kriteria } \\
\text { Kevalidar }\end{array}$} \\
\hline & & $\sum \mathrm{X}$ & $\sum \mathbf{X i}$ & & \\
\hline & Ahli E-Modul & 70 & 70 & $100 \%$ & $\begin{array}{l}\text { Sangat } \\
\text { Layak }\end{array}$ \\
\hline & Ahli Materi & 71 & 75 & $95 \%$ & $\begin{array}{l}\text { Sangat } \\
\text { Layak }\end{array}$ \\
\hline & $\begin{array}{l}\text { Uji coba kelompok kecil (6 Peserta } \\
\text { didik) }\end{array}$ & 426 & 480 & $89 \%$ & $\begin{array}{l}\text { Sangat } \\
\text { Layak }\end{array}$ \\
\hline & $x=\frac{\sum x}{\sum x i} x 100 \%$ & 567 & 625 & $94,667 \%$ & $\begin{array}{l}\text { Sangat } \\
\text { Layak }\end{array}$ \\
\hline
\end{tabular}

Table used by permission (CSafitri, Sania Nanda 2021. Data hasil validasi keseluruhan.

Berdasarkan hasil data validasi keseluruhan dapat disimpulkan E-Modul berbasis Aplikasi Flipbook PDF Corporate yang sedang dikembangkan oleh peneliti dari segi kelayakan bahasa, penyajian, isi, dan desain diperoleh keseluruhan hasil persentase sebesar $94,667 \%$ yang menunjukkan produk E-Modul berbasis Aplikasi Flipbook PDF Corporate yang dikembangkan peneliti masuk dalam kriteria "Sangat layak" digunakan sebagai sumber bahan ajar E-Modul pada mata pelajaran Korespondensi Kelas X Otomatisasi Tata Kelola Perkantoran Kompetensi Dasar 3.5 Menerapkan Tata Naskah Surat Menyurat Bahasa Inggris atau Bahasa Asing Lainnya 4.5 Membuat naskah surat menyurat Bahasa Inggris atau bahasa asing lainnya. Kompetensi Dasar Kompetensi Dasar 3.6 Menerapkan tata cara pembuatan surat pribadi dan 4.6 Membuat surat pribadi di SMK Muhammadiyah 7 Gondanglegi. Hal ini senada dengan dengan penelitian sebelumnya, bahwa menggunakan cara validasi terhadap ahli untuk melihat valid atau layaknya produk yang dikembangkan (Aprillia, Nuswowati and Susilaningsih, 2015; Utami et al., 2018; Oktaviara and Pahlevi, 2019). Suatu tes dapat dikatakan memiliki validitas apabila tes tersebut dapat mengukur objek dan sesuai dengan kriteria tertentu (Amalia and Widayati, 2012).

E-Modul berbasis Aplikasi Flipbook PDF Corporate menyajikan ilustrasi menarik yang dapat membantu peserta didik mengoperasikan E-Modul dengan mudah dan menarik, karena untuk memotivasi semangat belajar peserta didik. Ilustrasi dibuat untuk memberi variasi pada bahan ajar, sehingga menjadi lebih menarik, memotivasi, komunikatif, dan lebih memudahkan peserta didik untuk membaca, mengingat dan memahami materi pada Korespondensi (Pratama and Yasa, 2020). Tampilan bagian ilustrasi E-Modul berbasis Aplikasi Flipbook PDF Corporate dapat dilihat pada Gambar 3 berikut ini: 
Jurnal Ekonomi, Bisnis dan Pendidikan, 1(6), 2021, 558-599

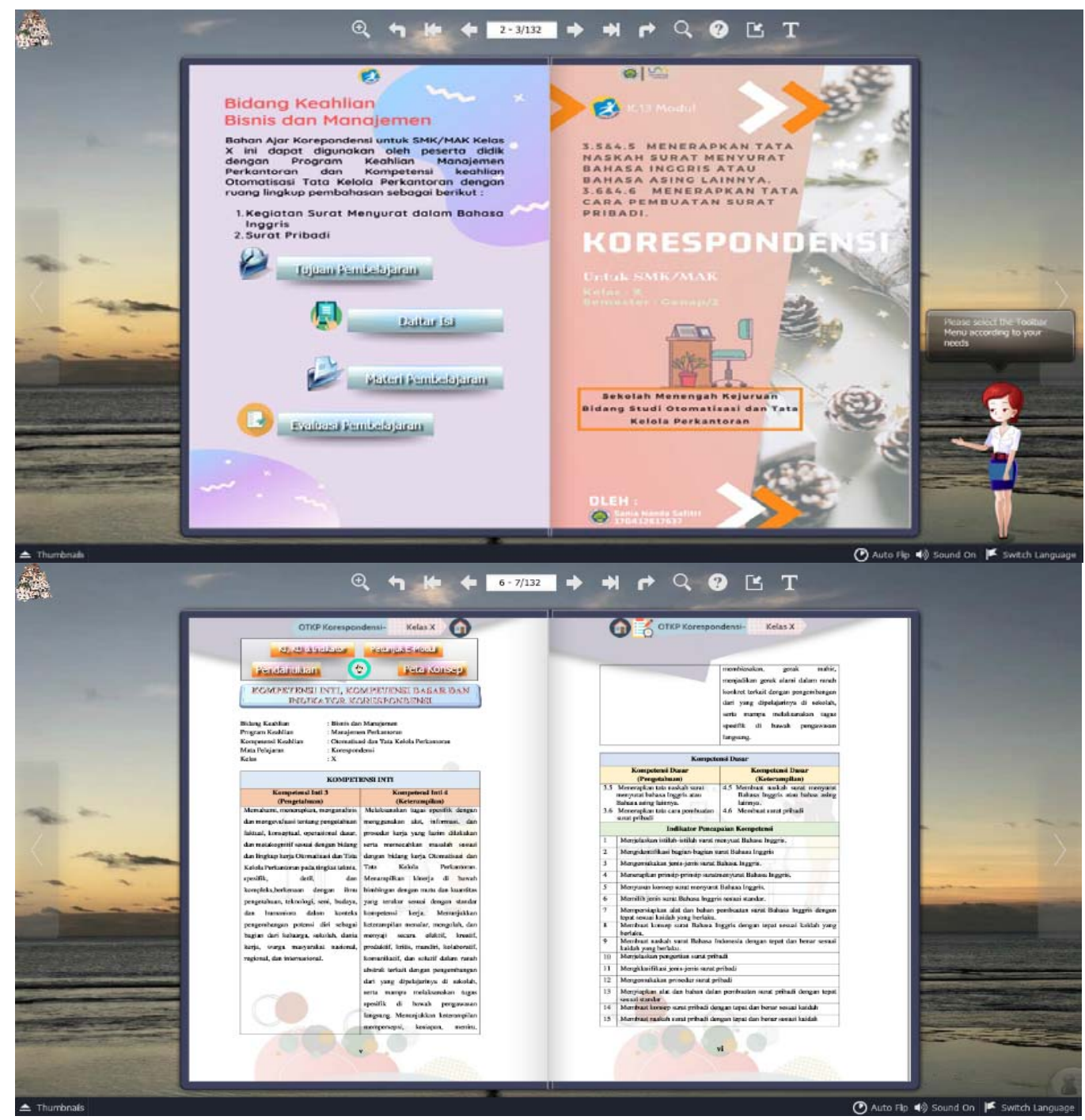

\section{Gambar 3. Ilustrasi pada $E$-Modul}

Sedangkan hasil data uji coba pemakaian pada kelompok besar menggunakan uji independent sample t-test pada data keterampilan menulis surat peserta didik kelas eksperimen dan kelas kontrol disajikan dalam Tabel 2 berikut ini: 
Tabel 2. Hasil uji independent sample t-test

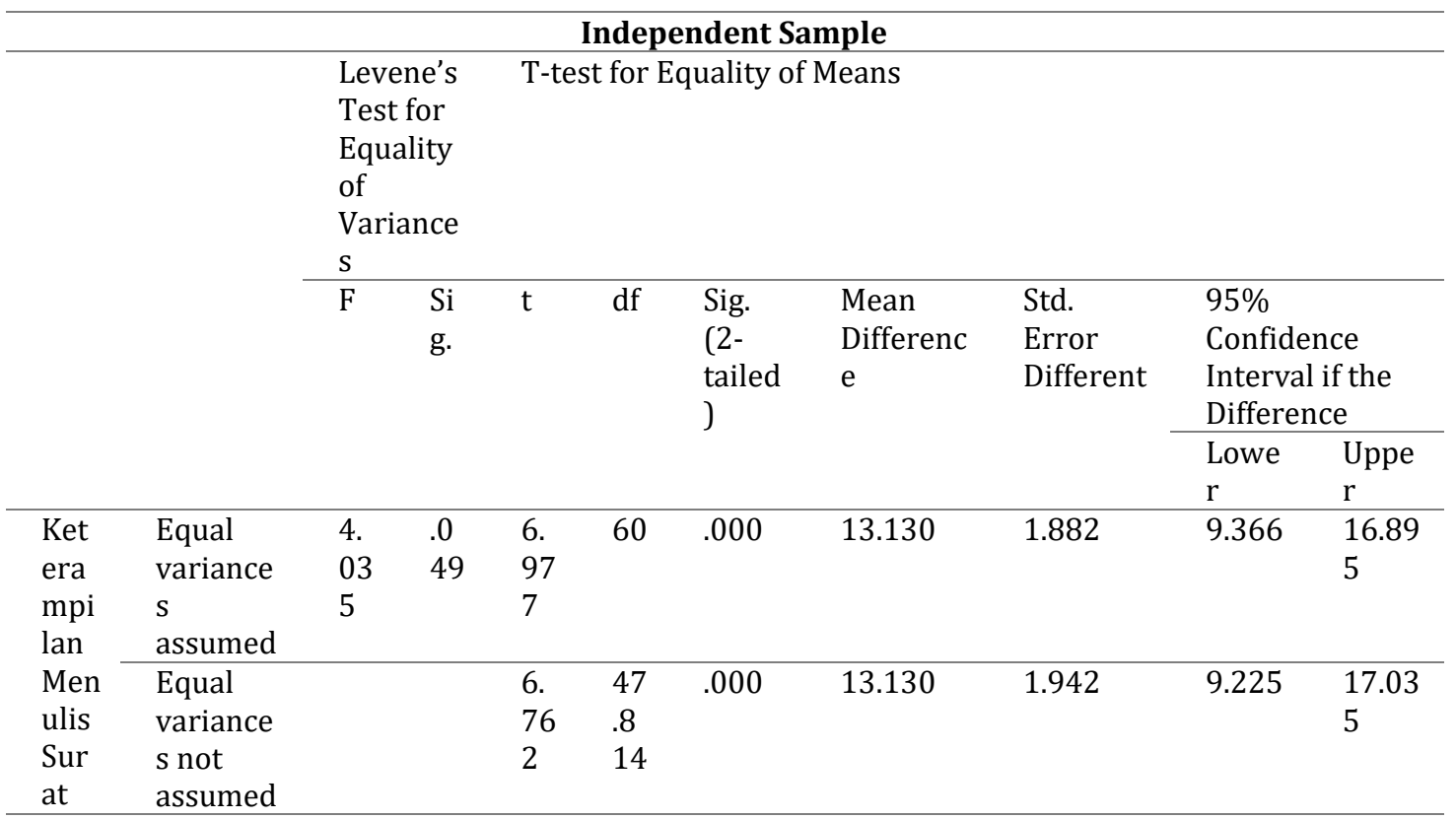

Table used by permission (CSafitri, Sania Nanda. 2021. Hasil uji independent sample t-test.

Berdasarkan Tabel 2. Hasil Uji Independent T-test Keterampilan Menulis Surat Peserta Didik pada SPSS versi 24 diketahui nilai Sig. Levene's Test for Equality of Variances sebesar $0,049>0,05$, maka dapat disimpulkan $\mathrm{H}_{\mathrm{o}}$ diterima dan $\mathrm{H}_{\mathrm{a}}$ ditolak, artinya Equal variances assumed atau varian data diasumsikan sama (homogen). Hasil Uji Independent T-test selanjutnya pada data bagian tabel Equality of Variances diketahui nilai Sig. (2-tailed) sebesar $0.000<0,05$. Kesimpulan pada data tersebut bahwa dasar dalam pengambilan keputusan dalam uji Independent $T$-test adalah $\mathrm{H}_{\mathrm{o}}$ ditolak dan $\mathrm{H}_{\mathrm{a}}$ diterima.

Kesimpulan yang didapat pada data dan analisis diatas adalah terdapat perbedaan yang signifikan (nyata) antara rata-rata keterampilan menulis surat peserta didik dari hasil nilai uji kompetensi kelas eksperimen dan kelas kontrol. Data statistik deskriptif kelas eksperimen dan kelas kontrol menunjukkan perbedaan hasil nilai rata-rata keterampilan menulis surat peserta didik kelas eksperimen dan kelas kontrol dapat dilihat pada Tabel 3 Hasil deskriptif statistik keterampilan menulis surat peserta didik.

Tabel 3. Hasil deskriptif statistic keterampilan menulis surat peserta didik

\begin{tabular}{lllllll}
\hline \multicolumn{7}{c}{ Descriptive Statistics } \\
\hline Kelas & N & Minimum & Maximum & Mean & $\begin{array}{l}\text { Std, } \\
\text { Deviation }\end{array}$ \\
\hline Keterampilan & Eksperimen & 34 & 70 & 98 & 85.56 & 6.190 \\
Menulis Surat & Kontrol & 27 & 60 & 88 & 72.43 & 8.604 \\
\hline Valid N (hiswist) & & & & & \\
\hline
\end{tabular}

Table used by permission (CSafitri, Sania Nanda. 2021. Hasil deskriptif statistic keterampilan menulis surat peserta didik.

Berdasarkan Tabel 3 Dapat dilihat perbedaan keterampilan menulis surat peserta didik pada hasil nilai rata-rata tes keterampilan kelas eksperimen dan kelas kontrol. Nilai rata-rata 
Jurnal Ekonomi, Bisnis dan Pendidikan, 1(6), 2021, 558-599

keterampilan menulis surat peserta didik pada kelas eksperimen adalah sebesar 85.56, sementara rata-rata keterampilan menulis surat peserta didik pada kelas kontrol adalah sebesar 72.43 .

Kesimpulan dari analisis data keterampilan menulis surat peserta didik bahwa penggunaan E-Modul berbasis Aplikasi Flipbook PDF Corporate pada mata pelajaran korespondensi kelas X Otomatisasi Tata Kelola Perkantoran Kompetensi Dasar menerapkan tata naskah surat menyurat bahasa Inggris atau Bahasa asing lainnya dikatakan efektif digunakan dalam kegiatan proses pembelajaran, karena bahan ajar E-Modul yang signifikan dalam meningkatkan keterampilan menulis surat peserta didik.

Peningkatan keterampilan menulis surat dan kemandirian belajar peserta didik yang signifikan pada penelitian ini disebabkan oleh peserta didik aktif dalam kegiatan pembelajaran daring dengan menggunakan E-Modul berbasis Aplikasi Flipbook PDF Corporate, peserta didik mudah melakukan kegiatan praktikum latihan menulis surat pada setiap sub bab materi, peserta didik termotivasi belajar secara mandiri. Keunggulan bahan ajar berupa E-Module adalah siswa dengan mudah mengakses pembelajaran dengan menggunakan berbagai jenis Smartphone atau Laptop/PC dimana saja dan kapan saja (Syamsurizal, Haryanto and Chairani, 2015). Tampilan materi dan evaluasi pembelajaran peserta didik dalam E-Modul berbasis Aplikasi Flipbook PDF Corporate dapat dilihat pada Gambar 4 berikut: 


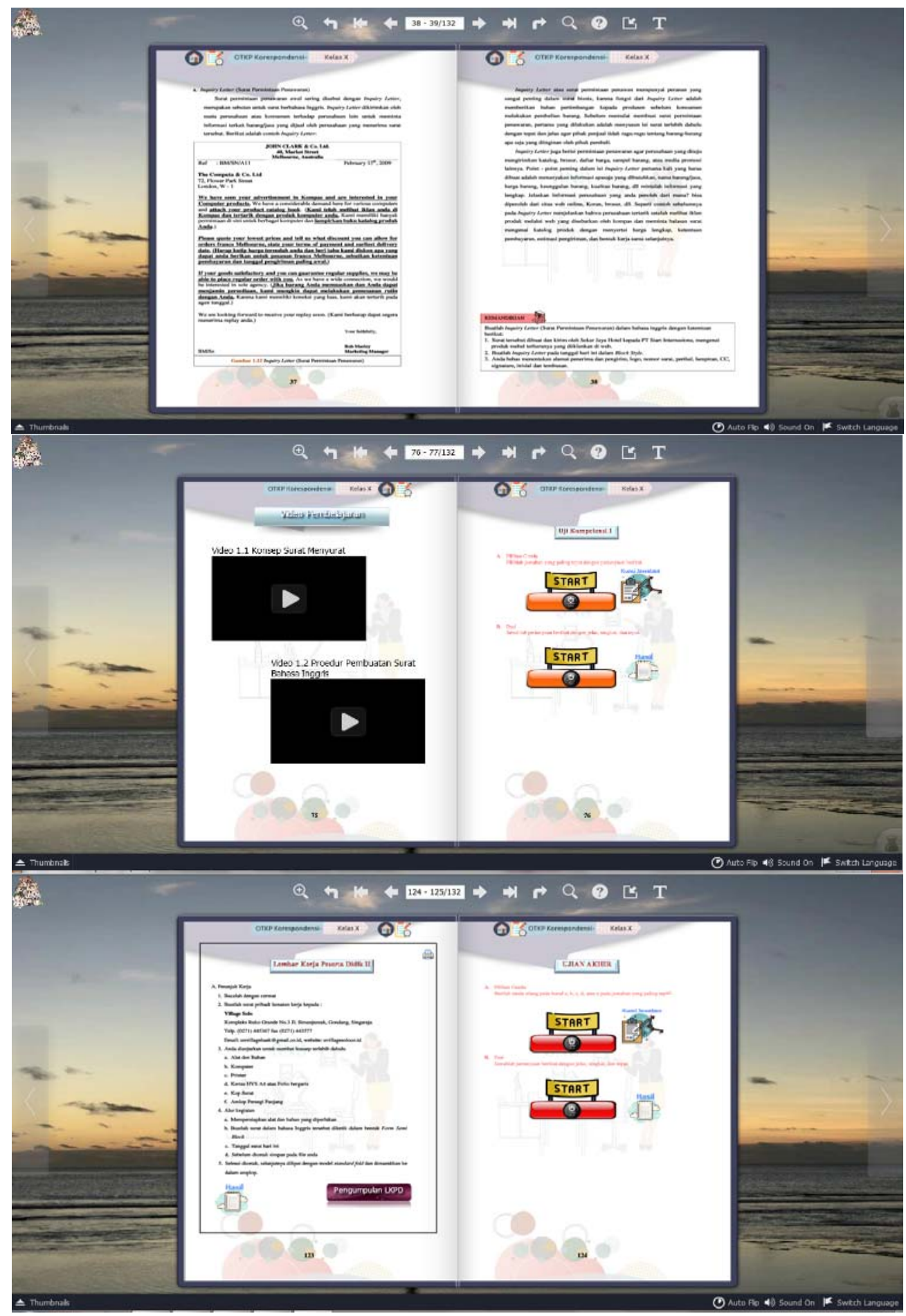

Gambar 4. Tampilan materi dan evaluasi pembelajaran

\section{Simpulan}

Produk yang telah dikembangkan dalam penelitian ini berupa bahan ajar elektronik, yaitu E-Modul berbasis Aplikasi Flipbook PDF Corporate untuk meningkatkan keterampilan menulis surat dan kemandirian belajar peserta didik kelas X Kompetensi Keahlian Otomatisasi 
dan Tata Kelola Perkantoran di SMK Muhammadiyah 7 Gondanglegi yang telah direvisi pasca mendapat masukan dari ahli media, ahli E-Modul, dan uji coba pemakaian pada kelompok kecil.

E-Modul pada penelitian ini masuk dalam kategori "Sangat Layak" dalam kegiatan pembelajaran secara daring sehingga produk yang dikembangkan peneliti dinyatakan bahwa E-Modul berbasis Aplikasi Flipbook PDF Corporate. Terdapat perbedaan yang signifikan antara hasil keterampilan menulis surat peserta didik dan kemandirian belajar kelas eksperimen (kelas yang menggunakan bahan ajar E-Modul berbasis Aplikasi Flipbook PDF Corporate) yaitu kelas X OTKP 1 dan kelas kontrol (kelas yang tidak menggunakan bahan ajar E-Modul berbasis Aplikasi Flipbook PDF Corporate). Hal ini dapat disimpulkan bahwa pengguna E-Modul berbasis Aplikasi Flipbook PDF Corporate efektif untuk meningkatkan keterampilan menulis peserta didik dan kemandirian belajar peserta didik

E-Modul berbasis Aplikasi Flipbook PDF Corporate focus pada mata pelajaran Korespondensi dengan $4 \mathrm{KD}$, harapan untuk peneliti selanjutnya pengembangan produk sebaiknya dapat menambah kompetensi dasar yang ada pada mata pelajaran Korespondensi dan mata pelajaran lainnya. Pengembangan bahan ajar E-Modul selanjutnya diharapkan memiliki kreatifitas yang lebih untuk mengembangkan desain, tombol-tombol navigasi dan fungsi-fungsi lainnya lebih menarik dan interaktif. Bahan ajar E-Modul berbasis Aplikasi Flipbook PDF Corporate dapat digunakan secara Offline melalui Laptop/PC dan secara online melalui Smartphone. Untuk pengembang lebih lanjut diharapkan nanti produk dapat diakses secara Offline melalui Smartphone.

\section{Ucapan Terima Kasih}

Penulis mengucapkan terimakasih kepada Universitas Negeri Malang yang telah memfasilitasi dan memberi izin kepada peneliti untuk melakukan kegiatan penelitian dan pengembangan ini.

\section{Daftar Rujukan}

Abdullah, R. (2012) 'Pembelajaran Berbasis Pemanfaatan Sumber Belajar', Jurnal Ilmiah Didaktika, 12(2), Pp. 216-231. Doi: $10.22373 / J i d . V 12 i 2.449$.

Amalia, A. N. And Widayati, A. (2012) 'Analisis Butir Soal Tes Kendali Mutu Kelas Xii Sma Mata Pelajaran Ekonomi Akuntansi Di Kota Yogyakarta Tahun 2012', Jurnal Pendidikan Akuntansi Indonesia, 10(1). Doi: 10.21831/Jpai.V10i1.919.

Andini, M. A. And Churiyah, M. (2020) Pengembangan E-Modul Exelearning Untuk Meningkatkan Keterampilan Siswa Dalam Mengelola Arsip. Edited By M. E. Andro Agil Nur Rakhmad, S.Ei, M. M. Dediek Tri Kurniawan, S.E., And M. P. Ika Zutiasari, S.Pd. Malang: Universitas Negeri Malang. Available At: Http://Manajemen.Fe.Um.Ac.Id/Wp-Content/Uploads/2020/09/Prosiding-Seminar-Nasional-IlmuManajemen-2020-Cetak.Pdf.

Aprillia, Indah Triana, Nuswowati, M. And Susilaningsih, E. (2015) 'Pengembangan Media Flash Berbasis Pembelajaran Inkuiri Untuk Meningkatkan Hasil Belajar Siswa', Jurnal Inovasi Pendidikan Kimia, 9(2). Available At: Http://Lib.Unnes.Ac.Id/Id/Eprint/22882.

Churiyah, M., Aulia, A. And Eko, B. (2020) 'Collage Students ' Usage Of E -Module Practicum For Increase Srl', Basic And Applied Research (Ijsbar), 54, Pp. 170-185. Available At: Http://Gssrr.Org/Index.Php?Journal=Journalofbasicandap-.

Dewi, W. A. F. (2020) 'Dampak Covid-19 Terhadap Implementasi Pembelajaran Daring Di Sekolah Dasar', Edukatif: Jurnal Ilmu Pendidikan, 2(1), Pp. 55-61. Doi: 10.31004/Edukatif.V2i1.89.

Fausih, M. And T, D. (2015) ‘Pengembangan Media E-Modul Mata Pelajaran Produktif Pokok Bahasan "Instalasi Jaringan Lan ( Local Area Network )” Untuk Siswa Kelas Xi Jurusan Teknik Komputer Jaringan Di Smk Negeri 1 Labang Bangkalan Madura', Jurnal Nasional Pendidikan Teknik Informatika, 01(01), Pp. 1-9. Available At: Https://Jurnalmahasiswa.Unesa.Ac.Id/Index.Php/Jmtp/Article/View/10375. 
Fitriningtias, N. And Churiyah, M. (2018) 'Improve Correspondence Learning Outcomes And Problem-Solving Capabilities By Developing Modules Based On Problem Based Learning', Jurnal Pendidikan Bisnis Dan Manajemen, 4(2), Pp. 67-83. Doi: 10.17977/Um003v4i22018p067.

Ngafifi, M. (2014) 'Kemajuan Teknologi Dan Pola Hidup Manusia Dalam Perspektif Sosial Budaya', Jurnal Pembangunan Pendidikan: Fondasi Dan Aplikasi, 2(1), Pp. 33-47. Doi: 10.21831/Jppfa.V2i1.2616.

Oktaviara, R. A. And Pahlevi, T. (2019) 'Pengembangan E-Modul Berbantuan Kvisoft Flipbook Maker Berbasis Pendekatan Saintifik Pada Materi Menerapkan Pengoperasian Aplikasi Pengolah Kata Kelas X Otkp 3 Smkn 2 Blitar Rhesta Ayu Oktaviara Triesninda Pahlevi', Jurnal Pendidikan Perkantoran, 07(03), Pp. 6065. Available Https://Jurnalmahasiswa.Unesa.Ac.Id/Index.Php/Jpapunesa/Article/Viewfile/29542/27066.

Pratama, R. J. And Yasa, I. N. M. (2020) 'Perancangan Buku Ilustrasi Sebagai Media Informasi Tentang Stres', Jurnal Sasak: Desain Visual Dan Komunikasi, 2(2), Pp. 59-66. Doi: 10.30812/Sasak.V2i2.864.

Putra, K. W. B., Wirawan, I. M. A. And Pradnyana, G. A. (2017) 'Pengembangan E-Modul Berbasis Model Pembelajaran Discovery Learning Pada Mata Pelajaran "Sistem Komputer" Untuk Siswa Kelas X Multimedia Smk Negeri 3 Singaraja', Jurnal Pendidikan Teknologi Dan Kejuruan, 14(1), Pp. 40-49. Doi: 10.23887/Jptk.V14i1.9880.

Shobahah, E. N. (2018) 'Pengembangan E-Modul Digital Flipbook Berbasis Discovery Learning Pada Materi Sistem Penyimpanan Arsip Kelas X Otkp 1 Di Smkn 10 Surabaya', Jurnal Pendidikan Administrasi Perkantoran, 6(1), Pp. 70-77. Available At: Https://Ejournal.Unesa.Ac.Id/Index.Php/Jpapunesa/Article/View/24511/22432.

Sugianto, D. Et Al. (2013) 'Modul Virtual : Multimedia Flipbook Dasar Teknik Digital', Invotec, Ix(2), Pp. 101116. Available At: Https://Ejournal.Upi.Edu/Index.Php/Invotec/Article/View/4860.

Sugiyono (2006) Metode Penelitian Pendidikan Pendekatan Kuantitatif, Kualitatif, Dan R\&D. Bandung: Penerbit Alfabeta.

Syamsurizal, Haryanto And Chairani, N. (2015) 'Pengembangan E-Modul Berbasis Keterampilan Proses Sains Pada Materi Kesetimbangam Kimia Untuk Tingkat Sma', Prosiding Semirata, Pp. 655-661. Available At: Https://Jurnal.Untan.Ac.Id/Index.Php/Semirata2015/Article/View/14286.

Utami, R. E. Et Al. (2018) 'Pengembangan E-Modul Berbasis Etnomatematika Untuk Meningkatkan Kemampuan Pemecahan Masalah', Jnpm (Jurnal Nasional Pendidikan Matematika), 2(2), P. 268. Doi: 10.33603/Jnpm.V2i2.1458.

Wibowo, E. And Pratiwi, D. D. (2018) 'Pengembangan Bahan Ajar Menggunakan Aplikasi Kvisoft Flipbook Maker Materi Himpunan', Desimal: Jurnal Matematika, 1(2), P. 147. Doi: 10.24042/Djm.V1i2.2279.

Widodo, C. And Jasmadi (2008) Panduan Menyusun Bahan Ajar Berbasis Kompetensi. Jakarta: Pt. Alex Media Komputindo.

Wirasari, Y. M. And Churiyah, M. (2016) 'Developing Learning Material Of Business Principles Using Scientific Approach To Improve Students ' Achievement', Iosr Journal Of Research \& Method In Education (IosrJrme), 6(3), Pp. 7-13. Doi: 10.9790/7388-0603040713. 